\title{
KONTRIBUSI PENDAPATAN KELOMPOK USAHA PEREMPUAN PESISIR DALAM PENGOLAHAN HASIL PERIKANAN DI MANOKWARI
}

\author{
Income Contribution of Indigenous Women in Coastal Area \\ of Manokwari in Fishery Products \\ Selvi Tebaiy ${ }^{*}$, Juliana Leiwakabessy ${ }^{1}$, Eddy T Wambrauw ${ }^{2}$ \\ ${ }^{1}$ Jurusan Perikanan, FPIK UNIPA, Manokwari, 98314, Indonesia \\ 2 Jurusan Ilmu Kelautan, FPIK, UNIPA, Manokwari, 98314, Indonesia \\ * Korespondensi : s.tebay@unipa.ac.id
}

\begin{abstract}
ABSTRAK
Perempuan pesisir Manokwari memiliki lima macam usaha diantaranya pengolahan bakso dan kerupuk, ikan asin, ikan asar, abon ikan dan wisata kuliner. Penelitian ini dilakukan di pesisir Kabupaten Manokwari pada Agustus - Desember 2015. Tujuannya adalah untuk mengetahui jenis-jenis usaha di sektor perikanan yang dilakukan perempuan pesisir Manokwari serta kontribusinya terhadap pendapatan rumah tangga. Metode wawancara digunakan terhadap 38 responden perempuan pesisir Manokwari sesuai jenis usaha yang ditekuni. Data yang diperoleh, dianalisis dengan metode deskriptif kemudian ditampilkan dalam bentuk grafik dan persentase. Dari jenis usaha yang ditekuni perempuan pesisir Manokwari diperoleh pendapatan rata-rata tertinggi adalah usaha olahan bakso dan yaitu sebesar Rp. 10,460,000.00 per month/kelompok, dan terendah adalah pelaku usaha ikan asin sebesar Rp. 4,895,000,00 per bulan/kelompok. Kontribusi pendapatan Rumah Tangga Perikanan sebesar 80\% disumbangkan oleh kegiatan pengolahan hasil perikanan. Hasil ini membuktikan bahwa perlu ada pendampingan kelembagaan usaha mikro dan penyediaan pasar yang memadai bagi keberlangsungan usaha.
\end{abstract}

Kata kunci: perempuan pesisir, manokwari, pendapatan, pengolahan hasil perikanan

\begin{abstract}
Indigenous women who lives in Manokwari coastal area have five field of economic livelihoods activities such as fish ball and fish crackers, salted dry fish, smoked fish, spicy shredded fish and local culinary tourism. A field research was done in several sites of coastal area of Manokwari during August to December 2015. The objective of this research is to explore and define types of economic livelihood activities by Indigenous women and its contribution on household income. Involving 38th respondents with using questionnaire method did interviews. Analyzed data using statistic descriptive. Based on this research is found that fish ball and fish crackers were higher per month than others, i.e. IDR 10.460.000,00 per month/group. The lowest income was salted dried fish, i.e. IDR 4.895.000 per month/group. About $80 \%$ the main contribution of the fisheries sector is from fish product. In Addition, based on this research also show that it needs an effort to empower small-scale unit business and market availability for sustainability business in Manokwari.
\end{abstract}

Key words: coastal women, manokwari, income, fish products 


\section{PENDAHULUAN}

Masyarakat nelayan memiliki karakteristik yang berbeda dari masyarakat lainnya. Hal ini membuat mereka harus memiliki strategi yang berbeda untuk memenuhi kebutuhannya. Lingkungan fisik nelayan mempunyai karakteristik yang berbeda dengan petani, Istiana (2007). Sumberdaya perikanan mempunyai sifat sulit diramal serta sasaran target operasi penangkapannya bersifat dinamis.

Hal ini membuat usaha perikanan mempunyai resiko kerusakan dan kerugian yang tinggi serta pola pendapatan yang fluktuatif. Pendapatan usaha tangkap nelayan sangat berbeda dengan jenis usaha lainnya, seperti pedagang atau bahkan petani. Jika pedagang dapat mengkalkulasikan keuntungan yang diperolehnya setiap bulannya, begitu pula petani dapat memprediksi hasil panennya, maka tidak demikian dengan nelayan yang kegiatannya penuh dengan ketidakpastian (uncertainty) serta bersifat spekulatif dan fluktuatif, Wahyono $d k k$. (2001) dan Kusnadi (2007). Dalam kondisi ini keberadaan perempuan sebagai penyokong kebutuhan ekonomi rumah tangga sangat diperlukan mengingat penghasilan nelayan tidaklah menentu.

Kegiatan perikanan umumnya didominasi oleh kaum pria. Peran tradisional pria sebagai nelayan menyebabkan mereka dianggap lebih layak mendominasi sektor perikanan, sementara kaum perempuan tinggal di rumah sebagai pengasuh dan perawat keluarga. Dengan berkembangan teknologi dan tuntutan ekonomi keluarga maka kaum perempuan juga telah berpartisipasi dalam kegiatan pengolahan dan penjualan hasil tangkapan. Aspek lain yang juga dilakukan oleh kaum perempuan adalah adanya kontribusi dalam ekonomi rumah tangga perikanan (Harper $d k k ., 2013)$.
Keterlibatan wanita nelayan mengandung resiko untuk lebih memanfaatkan waktunya baik sebagai ibu rumah tangga, tenaga kerja dalam usaha perikanan maupun di luar usaha perikanan. Wanita mempunyai kewajiban untuk ikut serta melaksanakan kegiatan baik untuk kesejahteraan keluarganya juga untuk masyarakat (Zen, 2008). Jika dilihat dari kebutuhan pasar tenaga kerja di Indonesia terus mengalami perkembangan selama tahun 2014 dan 2015, di mana pekerjaan mengalami pertumbuhan sedangkan pengangguran terbuka mengalami pe-nurunan.

Fluktuasi penyerapan tenaga kerja masih terus belangsung disebabkan selain oleh siklus musim (seasonal unemployment), juga karena fenomena pengangguran struktural (structural unemployment) daripada pengangguran tetap. Situasi tersebut dipicu oleh ketersediaan lapangan kerja yang belum sesuai dengan bidang keahlian pencari kerja.

Tren ini menunjukkan persoalan struktural di pasar tenaga kerja Indonesia, dan menegaskan pentingnya kebijakan dan program pasar tenaga kerja untuk memfasilitasi alat kelengkapan pasar tenaga kerja dengan menyediakan layanan pekerjaan dan manfaat terkait bagi pekerja yang masih menganggur.

Angka pengangguran terbuka cenderung menurun selama beberapa tahun terakhir ini, dan angka ini diperkirakan di bawah 6 persen pada 2014. Ini menunjukkan bahwa target pengurangan pengangguran terbuka menjadi 5 hingga 6 persen, sebagaimana yang ditetapkan dalam Rencana Pembangunan Jangka Menengah (RPJM) 2010-2014, sudah berhasil tercapai. Meskipun demikian, pengangguran terbuka masih menjadi tantangan, terutama bagi kalangan muda, khususnya bila terjadi kemunduran ekonomi.

Penurunan angka pengangguran terbuka masih menyisakan persoalan lain, terutama dalam hal distribusi peran 
yang masih bias gender. Hasil yang dicapai laki-laki dan perempuan masih tidak merata (ILO, 2015). Sebagai contoh, di pasar tenaga kerja, segregasi pekerjaan untuk laki-laki dan perempuan masih terlihat jelas, di mana banyak perempuan melakukan pekerjaan dengan upah yang lebih rendah dan prospek pengembangan karir yang lebih terbatas. Tingkat partisipasi perempuan dalam angkatan kerja masih sangat rendah, dimana banyak perempuan dilaporkan melakukan kegiatan yang terkait dengan tanggung jawab keluarganya secara penuh. Meskipun demikian, sepanjang tahun ini, ada banyak perempuan yang beralih dari tidak aktif secara ekonomi menjadi angkatan kerja walaupun hanya sebagai pekerja pada usaha keluarga. Banyak di antara mereka berprofesi sebagai "pekerja rumahan", yang berhubungan dengan rantai suplai global, dan melakukan kegiatan pabrik dari rumah, serta memperoleh upah rendah atau tidak dibayar sama sekali. Memperkuat posisi mereka dalam rantai suplai global melalui perbaikan kondisi kerja adalah faktor penting untuk menyalurkan potensi produktif perempuan dalam membantu pertumbuhan dan daya saing perekonomian Indonesia di masa mendatang.

Jumlah total penduduk Kabupaten Manokwari Tahun 2014 adalah 150.179 jiwa, yang terdiri dari penduduk lakilaki 79.766 dan penduduk perempuan 70.413 jiwa. Sebaran jumlah penduduk mempengaruhi jumlah tenaga kerja di Kabupaten Manokwari. Tahun 2014 jika dilihat dari sebaran penduduk usia produktif (20-59 Tahun) maka terlihat adanya perbedaan antara laki-laki dan perempuan. Usia produktif Perempuan di Kabupaten Manokwari sebesar 46\% dan laki-laki 53\% (BPS Manokwari, 2014). Dari data ini terlihat bahwa jumlah penduduk perempuan usia produktif lebih rendah dari jumlah penduduk laki laki usia produktif. Hal ini berdampak pada jenis pekerjaan, curahan waktu kerja dan pendapatan dalam rumah tangga.
Jenis usaha yang dilakukan perempuan pesisir pada umumnya adalah usaha tanaman pangan, perkebunan, perikanan, peternakan, pertambangan galian, industri, perdagangan, kontruksi atau bangunan dan jasa angkutan (Kusnadi, 2014). Di Manokwari selain usaha dibidang perikanan, perempuan pesisir juga mengusahakan tanaman pangan, peternakan, perdagangan dan juga pertanian.

Berdasarkan hal hal yang telah dijabarkan dalam latar belakang maka penelitian ini bertujuan untuk: (1) mengetahui jenis-jenis usaha di sektor perikanan yang dilakukan oleh perempuan pesisir Manokwari, (2) mengetahui kontribusi pendapatan perempuan dalam Rumah Tangga Perikanan. Diharapkan tulisan ini berguna didalam memberikan informasi tentang jenis-jenis usaha perempuan pesisir dalam pengolahan hasil perikanan bagi pendapatan keluarga pesisir atau Rumah Tangga Perikanan.

\section{METODE PENELITIAN}

Penelitian ini dilakukan di wilayah pesisir Kabupaten Manokwari Provinsi Papua Barat, dengan menetapkan 4 titik pengamatan (Gambar 1). Data yang digunakan dalam kajian ini adalah data primer yang diperoleh di lapangan dengan menggunakan teknik wawancara mendalam menggunakan kuesioner terstruktur. Wawancara adalah suatu cara pengumpulan data yang digunakan untuk memperoleh informasi langsung dari sumbernya (Riduwan, 2002). Data sekunder berasal dari intansi pemerintah yang terkait serta hasil-hasil kajian sebelumnya yang relefan dan menunjang penelitian ini.

Data primer meliputi (1). Identitas responden, (2). Jenis Usaha, (3) Data pendapatan dan (4), Kontribusi pendapatan. Data yang dikumpulkan ditabulasi kemudian dianalisis dengan metode deskriptif melalui penafsiran data yang ada, dengan tujuan mendeskripsikan secara rinci suatu fenomena alami yang 
disertai interpretasi rasional terhadap kondisi di lapangan (Singarimbun dan Effendi, 1989). Hasil analisis ditampilkan dalam bentuk grafik dan persentase.

Responden yang digunakan dalam penelitian ini berjumlah 38 orang. Responden yang diambil adalah perem- puan pesisir yang melakukan usaha pengolahan ikan. Usaha yang dilakukan adalah pengolah abon ikan, pengolah kerupuk dan bakso ikan tenggiri, pengolah ikan asin, pengolah ikan asar atau asap serta pengolah makanan tradisional Papua.

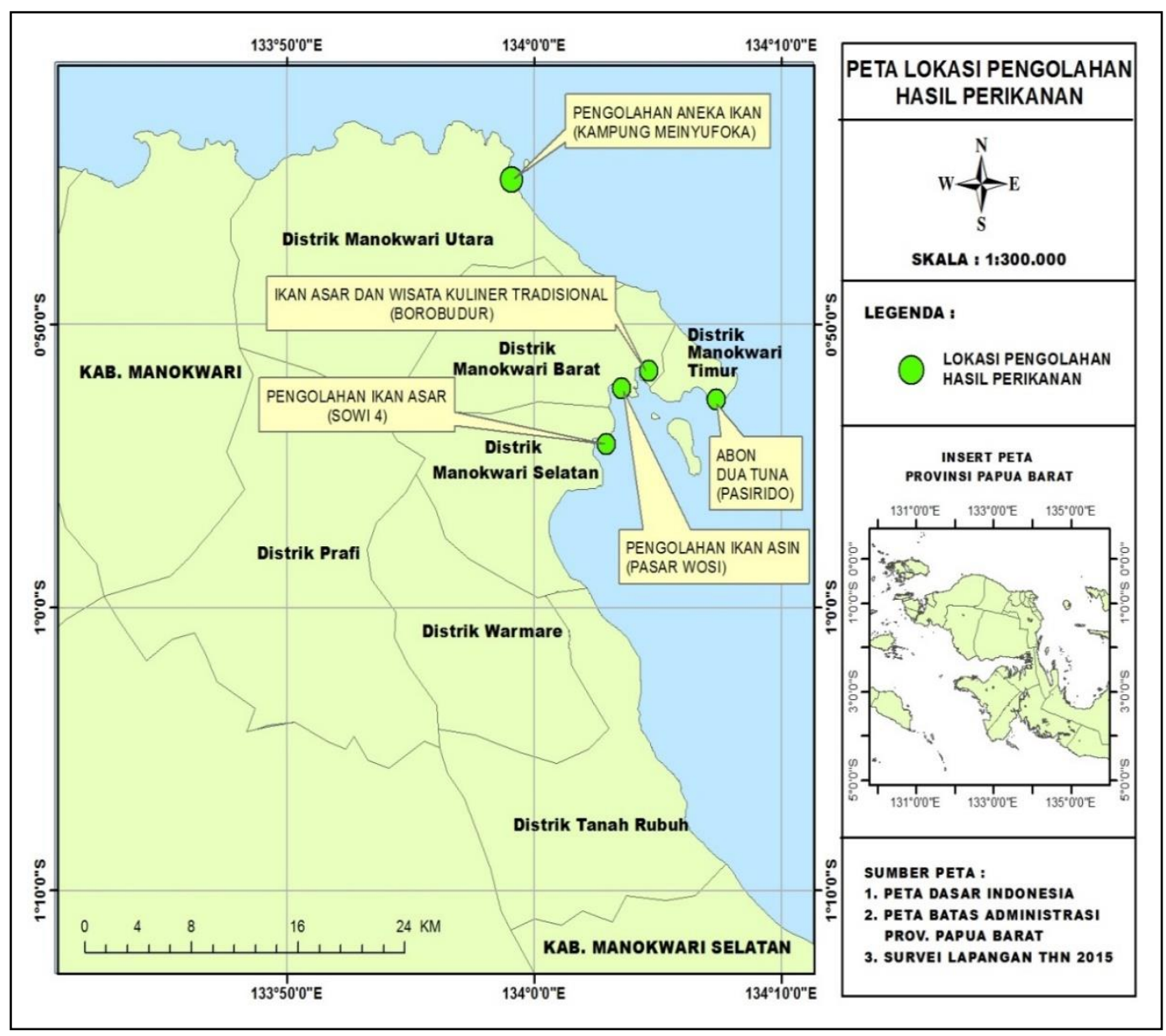

Gambar 1. Sebaran lokasi kelompok usaha pengolahan hasil perikanan di Pesisir Kabupaten Manokwari

Statistik deskriptif digunakan untuk mencari jumlah sampel, nilai maksimum dan minimum, rata-rata dan standar deviasinya. Hasil dari analisis kemudian diinterpretasikan untuk menjawab tujuan penelitian. Analisis dilakukan pada modal usaha, pendapatan, konsumsi dan kelembagaan. Untuk modal usaha dilakukan analisa usaha dengan menghitung besar biaya tetap, biaya variable, dan total penerimaan selama satu tahun sehingga diketahui struktur biaya, penerimaan, dan besarnya keuntungan (Soekartawi, 1995). Penghitungan keuntungan usaha menggunakan rumus :

$\pi=T R-T C$

Total Cost (TC) dihitung dengan rumus :

$T C=F C+V C$

Dimana 


$$
\begin{aligned}
Л= & \begin{array}{l}
\text { Keuntungan Usaha }(\text { Business } \\
\text { Profits) }
\end{array} \\
\mathrm{TR}= & \begin{array}{l}
\text { Total Penerimaan }(\text { Total } \\
\text { Revenue })
\end{array} \\
\mathrm{TC}= & \text { Total Biaya (Total Cost) } \\
\mathrm{FC}= & \text { Biaya Tetap (Fixed Costs) } \\
\mathrm{VC}= & \begin{array}{l}
\text { Biaya Variabel (Variable } \\
\text { Costs) }
\end{array}
\end{aligned}
$$

RC Ratio diperoleh melalui rumus :

$$
\mathrm{RC} \text { Ratio }=\frac{\mathrm{TR}}{\mathrm{TC}}
$$

Analisis pendapatan rumah tangga perikanan bertujuan untuk mengetahui besarnya pendapatan yang berasal dari pendapatan utama dan sampingan baik itu yang berasal dari kepala keluarga maupun anggota rumah tangganya. Analisis Regresi Linear Sederhana (RLS) digunakan untuk melihat kontribusi perempuan pesisir dalam meningkatkan pendapatan keluarga yang diketahui dari kontribusi pendapatan perempuan tersebut terhadap pendapatan keluarga (Zen, 2008). Dengan rumus sebagai berikut :

$\mathrm{K}=\frac{\mathrm{Pps}}{\mathrm{Pt}}$

Dimana :

$$
\begin{aligned}
& \mathrm{K}= \begin{array}{l}
\text { kontribusi pendapatan } \\
\text { perempuan pesisir }(\%)
\end{array} \\
& \text { pendapatan perempuan pesisir } \\
& \mathrm{Pps}= \\
&\mathrm{Rp})
\end{aligned}
$$

\section{HASIL DAN PEMBAHASAN}

\section{Karakteristik Perempuan Pengolah Hasil-hasil Perikanan di Pesisir Manokwari}

\section{Umur}

Perempuan pengolah hasil perikanan di pesisir Manokwari melaksanakan usaha pengolahan secara tradisional. Pada umumnya pola hidup mereka masih di bawah garis kemiskinan. Hal ini disebabkan ciri-ciri yang melekat pada mereka yaitu suatu kondisi yang subsisten dengan modal yang kecil, teknologi yang digunakan dan kemampuan/skill serta perilaku yang masih tradisional, baik dari segi keterampilan, psikologi dan mentalitas (Susilowati, 1991).

Karakteristik umur perempuan pengolah hasil perikanan di pesisir Manokwari terdistribusi ke dalam 4 (empat) kelompok umur responden, dimana terbesar yaitu usia 41-50 tahun sebanyak $43 \%$, usia 31- 40 tahun sebesar 24\%. Responden dengan umur 51-60 tahun sebanyak $14 \%$ sedangkan kelompok dengan usia 61-70 tahun sebanyak 19\%. (Gambar 2).

Sebaran umur terlihat bahwa persentase terbesar berada pada usia produktif yang mapan dalam menghasilkan usaha sebagai pendapatan keluarga. Pada umunya wanita nelayan di kampung Borobudur terlibat dalam kegiatan pengolahan hasil perikanan pada kategori umur 18-63 Tahun (Emping dan Widiastuti, 2013).

Hal ini dipengaruhi oleh keputusan mereka untuk menikah dan putus sekolah pada usia muda, sehingga tidak memiliki keterampilan lain sementara beban keluarga semakin besar dari waktu ke waktu sejalan dengan bertambahnya jumlah anggota keluarga akibat kelahiran. Kondisi keluarga mengharuskan mereka harus mengambil peran sebagai tulang punggung keluarga berupa kegiatan pengolahan dan pemasaran hasil ikan ikan olahan.

Penelitian terdahulu yang dilakukan oleh Swaminathan (1997), Lisa (2000), Bardegue dkk. (2001), dan Elbers dan Lanjouw (2001), menunjukkan bahwa umur mempunyai pengaruh terhadap pendapatan. Pengaruh umur terhadap pendapatan memang tidak besar (nilai koefisien parameter antara 0.023 hingga 0.106). Meskipun umur memang mempunyai pengaruh terhadap pendapatan. 


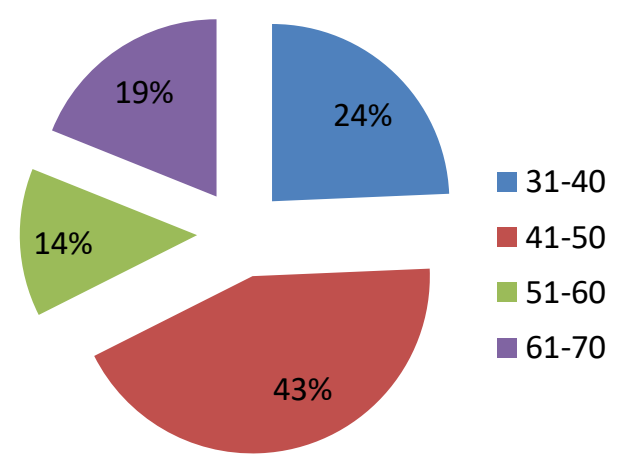

Gambar 2. Sebaran Umur Responden (Tahun 2015)

\section{Pendidikan}

Tingkat pendidikan formal berdasarkan sebaran tingkat pendidikan responden perempuan pengolah hasil perikanan di pesisir manokwari tergolong rendah. Sebanyak 54\% adalah mereka yang menamatkan pendidikan Sekolah
Dasar (SD), 24\% menamatkan pendidikan SMP, sedangkan untuk tingkat pendidikan SMU hanya $16 \%$. Pada tingkat Perguruan Tinggi dan Tidak mengecam pendidikan masing-masing sebanyak 3\% (Gambar 3).

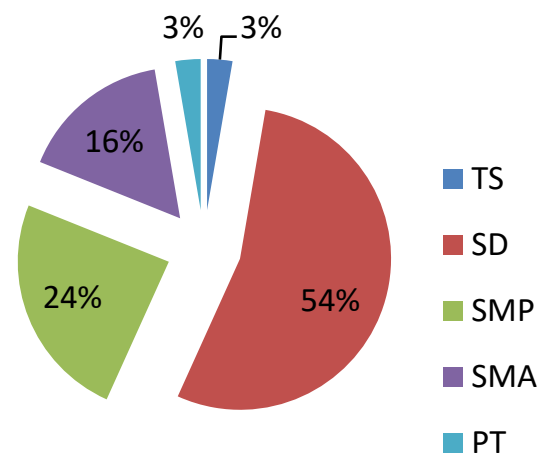

Gambar 3. Sebaran Tingkat Pendidikan Responden (Tahun 2015)

Penyebab rendahnya tingkat pendidikan formal pada perempuan pengolah hasil perikanan adalah karena kondisi ekonomi keluarga yang lemah, keterbatasan biaya di lingkungan tempat tinggal mereka, serta pola berfikir atau pandangan tentang pentingnya pendidikan. Adanya anggapan bahwa pekerjaan perempuan hanya berkisar di rumah saja, (Emping at al, 2013). Hasil kajian Yulisti dkk. (2009), menunjukkan bahwa tingkat pendidikan istri nelayan di Kabupaten Sukabumi terbesar adalah pada tingkat Sekolah Dasar (SD). Pendidikan akan mempengaruhi kemam- puan penyerapan informasi baru dalam mengembangkan aneka olahan ikan.

Tingkat pendidikan mempunyai pengaruh terhadap pendapatan (Swaminathan, 1997; Lisa, 2000; Bardegue dkk., 2001; Elbers dan Lanjouw, 2001; dan Naude dan Taylor, 2001). Nilai koefisien parameter variabel pendidikan antara 0.023 hingga 0.107. Ini dapat disimpulkan bahwa pendidikan memang mempunyai pengaruh terhadap pendapatan. 


\section{Jumlah Anggota Keluarga}

Sebaran jumlah tanggungan keluarga (Gambar 4), terlihat bahwa dalam satu keluarga pengolah hasil perikanan di pesisir Kabupaten Manokwari terdapat 6-7 orang dalam satu keluarga sebanyak $65 \%$. Jumlah dibawah 5 orang sebanyak $30 \%$ dan $5 \%$ menjelaskan jumlah diatas 8 (delapan) orang jumlah dalam keluarga.

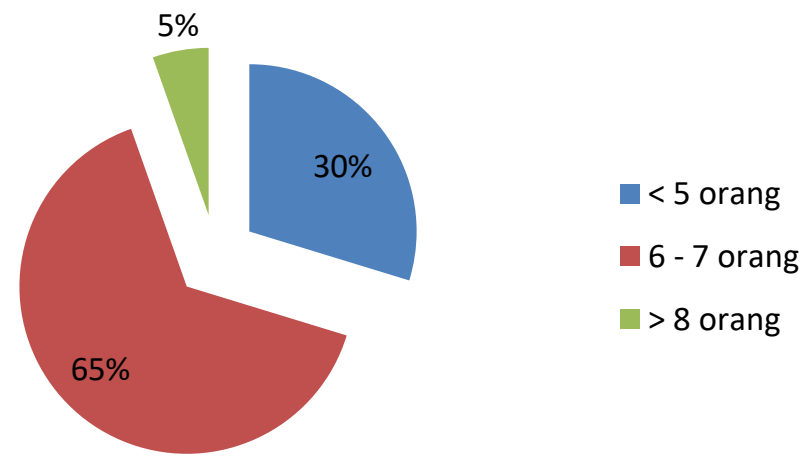

Gambar 4. Sebaran Jumlah Tanggungan Keluarga Responden (Tahun 2015)

Variabel lain yang berpengaruh terhadap pendapatan adalah jumlah anggota keluarga. Pengkaji-pengkaji seperti Firdaussy dan Tisdel (1992), Naude dan Taylor (2001), Elbers dan Lanjouw (2001) menggunakan variabel jumlah anggota keluarga sebagai salah satu faktor yang mempengaruhi pendapatan. Firdaussy dan Tisdel (1992) menggunakan data kerat rentas (cross section) untuk mengkaji pendapatan dan kemiskinan di tiga pedesaan Bali, Indonesia.

Jumlah keluarga adalah suatu faktor penting yang mempengaruhi kemiskinan rumah tangga (contoh Chemichovsky dan Meesok, 1984; Sigit, 1985; Alamgir dan Ahmed, 1988; Kuznets, 1989; Gaiha, 1989; Firdaussy, 1992). Faktor ini mempengaruhi kemiskinan dalam dua arah: pertama, mungkin secara langsung mempengaruhi kemiskinan, selama pendapatan rumah tangga tetap, meningkatnya jumlah keluarga akan menekan tingkatan konsumsi riil anggota keluarga; kedua, sekalipun tiap anggota rumah tangga mempunyai pendapatan, pendapatan per kapita dapat menurun dengan bertambahnya jumlah keluarga berkenaan dengan diminishing marginal productivity (Sigit, 1985, Kuznet, 1989, Firdaussy, 1992).

\section{Jenis Usaha yang dilakukan}

Berdasarkan hasil kajian yang dilakukan maka diperoleh data mengenai perempuan pesisir pengolah hasil perikanan (Gambar 5).

Jenis usaha terbesar dilakukan pada jenis usaha pengolah ikan asar sebesar 32\%. Usaha olahan ikan asar menjadi jenis usaha yang lebih banyak dilakukan oleh perempuan dibandingkan usaha lainnya. Hal ini didukung oleh ketersediaan bahan baku ikan yang lebih memudahkan proses produksi. Terlihat bahwa perempuan dengan jenis usaha ikan asar berada pada daerah Borobudur dan Sowi IV yang termasuk dalam perkampungan nelayan, sebagian besar mendapatkan bahan baku dari hasil tangkapan suami yang merupakan nelayan. Usaha wisata kuliner memiliki persentase responden terbanyak kedua yakni $27 \%$. Usaha abon ikan dan ikan asin sebanyak $14 \%$ dan terendahnya adala adalah usaha bakso ikan dan kerupuk. Tidak banyak perempuan pesisir yang melakukan usaha pembuatan bakso dan kerupuk ikan karena proses pembuatannya membutuhkan ketelitian dan waktu yang cukup lama. 


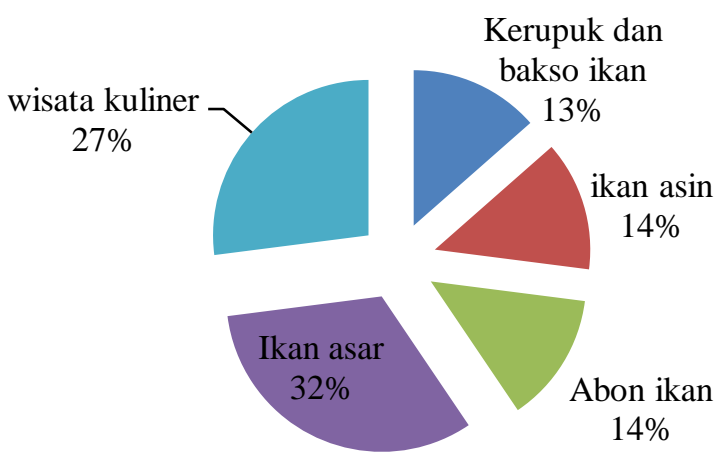

Gambar 5. Jenis Usaha Pengolahan Hasil Perikanan Perempuan Pesisir Manokwari

\section{Analisi Pendapatan}

\section{Komponen Penerimaan}

Sumber penerimaan perempuan pengolah hasil perikanan di pesisir
Manokwari berasal dari penerimaan jenis usaha bakso dan kerupuk ikan tenggiri, abon ikan tuna, ikan asin, ikan asar dan makanan olahan tradisional.

Tabel 1. Sebaran Penerimaan Produk olahan perikanan (Rp/bln)

\begin{tabular}{lcrr}
\hline \multicolumn{1}{c}{ Jenis usaha pengolahan } & Maksimum $(\mathbf{R p})$ & Minimum $(\mathbf{R p})$ & Rata-Rata $($ Rp) \\
\hline Kerupuk dan bakso tenggiri & $12,250,000.00$ & $3,500,000.00$ & $14,000,000.00$ \\
Pedagang ikan asin & $6,000,000.00$ & $4,000,000.00$ & $8,000,000.00$ \\
Abon Ikan & $11,250,000.00$ & $4,500,000.00$ & $13,500,000.00$ \\
Ikan asar & $10,000,000.00$ & $3,000,000.00$ & $11,500,000.00$ \\
Olahan tradisional & $7,500,000.00$ & $3,000,000.00$ & $9,000,000.00$ \\
\hline
\end{tabular}

Penerimaan hasil pengolahan berdasarkan Tabel 1 diatas terlihat bahwa dalam satu bulan, rata-rata penerimaan tertinggi digambarkan oleh jenis usaha pengolahan kerupuk dan bakso tenggiri serta abon ikan tuna. Pengolahan kerupuk dan bakso ikan tenggiri diproduksi sebanyak 12 kali dalam satu bulan dan sebesar $60 \%$ dari rata-rata penerimaan dihasilkan oleh olahan bakso ikan, selebihnya adalah berasal dari kerupuk ikan yakni $40 \%$. Jenis Usaha ikan asin memiliki rata-rata penerimaan yang lebih rendah dari semua jenis olahan yang dilakukan oleh perempuan pesisir manokwari sebesar Rp. 8,000,000, ikan asin dibeli di Sorong dan dipasarkan bersama dengan jenis usaha lainnya seperti warung sembako. Besarnya produksi (Tabel 2) dipengaruhi oleh kuantitas dari produk yang dihasilkan dan dipasarkan oleh perempuan pesisir Manokwari.

Produksi olahan tertinggi adalah jenis usaha kerupuk dan bakso tenggiri, Abon Ikan, ikan asar, ikan asin dan olahan makanan tradisional. Permintaan akan olahan kerupuk dan bakso ikan tenggiri dari KUBE Myos Aur Kampung Myumfoka terus berlangsung dan rutin. Hal ini sangat tergantung kepada ketersediaan pasar yang rutin sehingga produksi olahan dapat dihasilkan secara terus menerus. Empat olahan lainnya menjualkan hasil produksinya sendiri di pasar umum ataupun di toko-toko yang ada di Kabupaten Manokwari, sehingga terjadi persaingan pasar dengan produk yang sama dari tempat lain. 
Tabel 2. Sebaran produksi olahan dalam satu bulan

\begin{tabular}{llccc}
\hline \multicolumn{1}{c}{ Jenis usaha pengolahan } & \multicolumn{1}{c}{ Satuan } & Maksimum & Minimum & Rata-Rata \\
\hline Kerupuk dan bakso tenggiri & bungkus & 350 & 100 & 225 \\
Pedagang ikan asin & Kg & 300 & 200 & 250 \\
Abon Ikan & Bungkus & 150 & 75 & 113 \\
Ikan asar & Ekor & 200 & 60 & 130 \\
olahan tradisional & piring & 300 & 120 & 210 \\
\hline
\end{tabular}

\section{Komponen Biaya}

Dalam penelitian ini komponen biaya berasal dari Biaya Operasional (BO) dan Biaya Produksi (BP) yang terdiri dari Biaya Variabel dan Biaya Tetap (BV + BTT) (Tabel 3). Dimana kelompok biaya yang digunakan adalah disesuaikan dengan jenis usaha yang dilakukan. Biaya Tetap (kebutuhan alat produksi), Biaya Operasional (pinang dan rokok) dan Biaya Variabel seperti (ikan, es batu, kayu bakar).

Tabek 3. Komponen Biaya Pengolahan Hasil Perikanan (Rp/bulan)

\begin{tabular}{|c|c|c|c|c|}
\hline \multirow{2}{*}{ Jenis usaha pengolahan } & \multirow{2}{*}{$\begin{array}{c}\text { Biaya } \\
\text { Opersional }\end{array}$} & \multicolumn{2}{|c|}{ Biaya Produksi } & \multirow{2}{*}{ Total Biaya } \\
\hline & & Biaya Variabel & Biaya Tetap & \\
\hline $\begin{array}{l}\text { Kerupuk dan bakso } \\
\text { tenggiri }\end{array}$ & & & $200,000.00$ & $2,360,000.00$ \\
\hline ng ikan asin & & & & $2,070,000.00$ \\
\hline Abon Ikan & & $2,000,000.00$ & $40,000.00$ & $2,080,000.00$ \\
\hline Ikan asar & $100,000.00$ & $1,500,000.00$ & $500,000.00$ & $2,100,000.00$ \\
\hline Wisata kuliner & $250,000.00$ & $1,000,000.00$ & $500,000.00$ & $1,750,000.00$ \\
\hline
\end{tabular}

Biaya tertinggi dalam satu bulan digunakan oleh jenis usaha kerupuk dan bakso tenggiri Rp. 2,360,000 dan terendah pada jenis usaha olahan tradisional Rp. 1,750,000. Hal ini disebabkan sebagian besar alat produksi merupakan bantuan Pemerintah Daerah bagi pemberdayaan kemandirian ekonomi masyarakat.

\section{Pendapatan}

Pendapatan keluarga merupakan jumlah seluruh hasil pemasukan keluarga baik dari pendapatan suami dan pendapatan istri. Pendapatan istri atau pendapatan wanita nelayan juga dipengaruhi oleh hasil pemasaran yang dilakukan dalam kegiatan pemanfaatan sumberdaya perikanan (Purwanti, 2010). Berdasarkan Tabel 4, Sebaran pendapatan dari jenis-jenis usaha yang dilakukan dalam pengolahan hasil perikanan oleh perempuan pesisir Kabupaten Manokwari.

Pendapatan per bulan tertinggi pada jenis usaha kerupuk dan bakso tenggiri Rp. 10.460,000 dan produk abon ikan tuna Rp. 10,380,000. Produksi dalam satu bulan adalah sebanyak 12 kali produksi dengan hari kerja yang telah ditetapkan selama satu minggu sebanyak tiga kali (Senin, Rabu dan Jumat). Ketersediaan pasar yang baik menjadi salah satu faktor pendorong meningkatnya pendapatan usaha yang dilakukan. Pendapatan terendah Rp. 4.895,000 adalah jenis usaha ikan asin. 
Tabel 4. Distribusi Tingkat pendapatan pengolahan hasil perikanan ( $\mathrm{Rp} / \mathrm{b} / n / k e l o m p o k)$

\begin{tabular}{llrr}
\hline \multicolumn{1}{c}{ Jenis usaha pengolahan } & Maksimum (Rp) & Minimum (Rp) & Rata-Rata (Rp) \\
\hline Kerupuk dan bakso tenggiri & $9,890,000.00$ & $1,140,000.00$ & $10,460,000.00$ \\
Pedagang ikan asin & $3,930,000.00$ & $1,930,000.00$ & $4,895,000.00$ \\
Abon Ikan & $9,170,000.00$ & $2,420,000.00$ & $10,380,000.00$ \\
Ikan asar & $7,900,000.00$ & $900,000.00$ & $8,350,000.00$ \\
Wisata kuliner & $5,750,000.00$ & $1,250,000.00$ & $6,375,000.00$ \\
\hline
\end{tabular}

\section{Kontribusi Pendapatan Perempuan Pesisir dalam Rumah Tangga}

Kontribusi pendapatan perempuan pesisir terhadap total pendapatan keluarga (RTP) dapat dilihat dari jenis usaha perempuan pesisir dalam kegiatan ekonomi rumah tangga. Peran istri terhadap total pendapatan keluarga menurun dengan semakin baiknya kondisi keuangan rumah tangga. Peran wanita dalam rumah tangga berkaitan dengan pekerjaan yang dilakukan di dalam keluarga nelayan. Perananya dalam mencari nafkah dapat dilihat dari curahan jam kerja untuk menghasilkan pendapatan, dengan demikian kondisi kontribusi wanita tidak dapat diabaikan begitu saja (Hutapea, 2012).

Kontribusi pendapatan perempuan dalam pengolahan hasil perikanan di pesisir Kabupaten Manokwari berasal dari kelompok usaha pengolahan kerupuk dan bakso ikan di KUBE Myos Aur dan pedagang ikan asin memberikan kontribusi sebesar 62\%. Usaha abon ikan sebasar 61\%. Sedangkan usaha ikan asar dan makanan olahan tradisional (kuliner) Papua sebesar 80\% dari total pendapatan keluarga.

Kontribusi pendapatan perempuan yang bekerja disektor perikanan di kampung Borobudur dari usaha ikan asar, penjual ikan segar dan olahan makanan tradisional adalah sebesar 60,58\% menurut Emping (2013). Se- dangkan oleh Sabariah dkk. (2005) bahwa kontribusi perempuan Papua dalam pengolahan hasil perikanan di kampung Borobudur dan Fanindi Pantai adalah sebesar 26\%. Pada Tahun 2016 terjadi peningkatan kontribusi pendapatan oleh perempuan pesisir dalam melakukan usaha dibidang pengolahan hasil perikanan (Gambar 6).

Trend peningkatan kontribusi pendapatan dari jenis usaha aneka olahan ikan (tahun 2005-2015) berdasarkan analisis regresi menunjukan peningkatan yang signifikan sebesar $70 \%$. Hal ini menunjukan bahwa dengan diversifikasi jenis usaha olahan ikan memberikan peningkatan pendapatan dalam Rumah Tangga Perikanan yang didukung oleh lamanya curahan waktu bekerja. Curahan waktu kerja wanita secara garis besar dibagi menjadi dua yaitu: curahan waktu kerja untuk kegiatan ekonomi (mencari nafkah) dan kegiatan non ekonomi yaitu kegiatan dasar, kegiatan sosial dan kegiatan rumah tangga (Putri dkk., 2007).

Hasil penelitian Firdaus dkk. (2015) di Desa Penjajab Kabupaten Sambas, menunjukkan bahwa curahan waktu kerja istri nelayan rata-rata untuk kegiatan ekonomis adalah 4 jam/hari sedangkan untuk kepala keluarga yaitu 7 jam/hari. Jika diambil total nilai ratarata waktu kerja dalam seminggu maka 
diketahui bahwa untuk istri nelayan yaitu $28 \mathrm{jam} / \mathrm{minggu}$. Berdasarkan hal tersebut diketahui bahwa istri nelayan dapat tergolong kedalam kategori tenaga kerja setengah menganggur, sesuai dengan kategori yang ditentukan oleh Badan Pusat Statistik (2014) bahwa tenaga kerja yang jam kerjanya kurang dari $35 \mathrm{jam} /$ minggu tergolong kedalam tenaga kerja setengah menganggur. Untuk kepala keluarga tergolong dalam tenaga kerja penuh karena jam kerjanya lebih dari 35 jam/minggu.

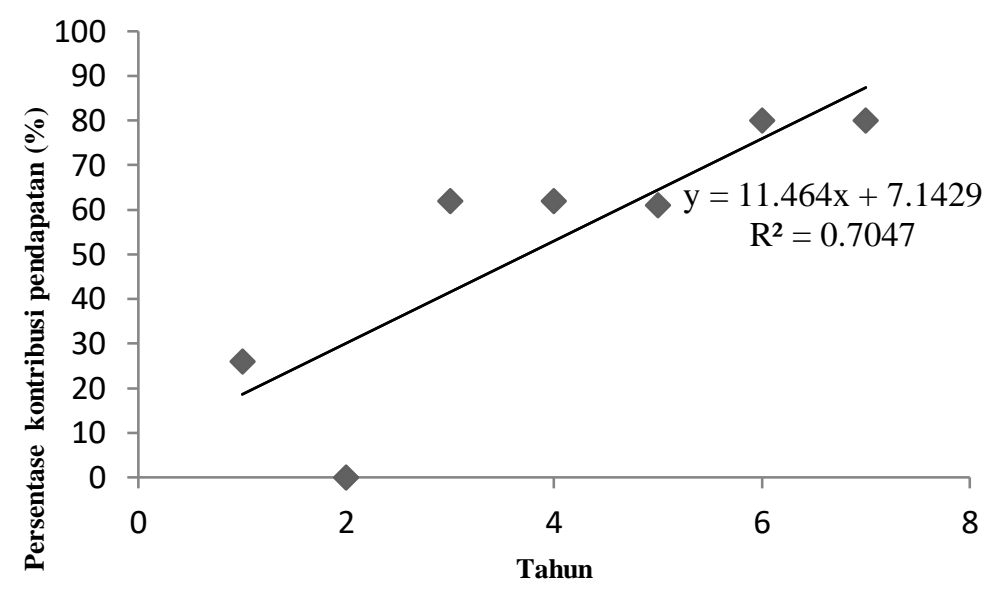

Gambar 6. Trend peningkatan kontribusi pendapatan perempuan dalam usaha pengolahan hasil perikanan di Kabupaten Manokwari (Tahun 2005-2015)

Hasil penelitian yang dilakukan oleh Handayani dan Artini (2009) pada istri nelayan pembuat makanan olahan di Kota Denpasar menunjukkan hal yang sama, bahwa istri nelayan dilokasi tersebut tergolong pada tenaga kerja setengah menganggur yang memiliki waktu kerja kurang dari 35 jam/minggu. Dengan memperhatikan rata-rata curahan waktu bekerja istri nelayan (4 $\mathrm{jam} / \mathrm{hari}$ ), secara umum dapat dikemukakan bahwa mereka masih mempunyai alokasi waktu yang dapat digunakan untuk kegiatan lain, seperti mengurus rumah tangga, istirahat ataupun kegiatan lain.

Keikutsertaan wanita dalam mencari tambahan nafkah bagi keluarga banyak menimbulkan perubahan bukan hanya perubahan yang menyangkut curahan waktu kerja kaum wanita terhadap pekerjaan rumah tangga (domestik) tetapi juga perubahan mencari kebutuhan rumah tangga serta perubahan adanya peningkatan pendapatan yang diperoleh (Singgih, dkk., 1990 in Jume'edy,2005).

\section{KESIMPULAN}

Berdasarkan hasil pengamatan dan analisis data, maka kesimpulan yang dapat diambil dari penelitian mengenai kontribusi pendapatan kelompok usaha perempuan pesisir dalam pengolahan hasil perikanan di Manokwari adalah sebagai berikut :

1. Lima jenis usaha yang dilakukan oleh perempuan pesisir Kabupaten Manokwari adalah pengolah bakso dan kerupuk ikan tenggiri, abon ikan, ikan asin, ikan asar dan wisata kuliner. Pendapatan rata-rata per bulan dari hasil olahan bakso dan kerupuk ikan tenggiri yang dikelola oleh KUBE Myos Aur dengan pendapatan tertinggi per bulan Rp. 10,460,000.00 dan terendah adalah pengusaha ikan asin Rp. 4,895,000.00.

2. Kontribusi pendapatan perempuan pengolah hasil perikanan dalam pendapatan rumah tangga adalah sebesar $80 \%$ dari usaha ikan asar dan wisata 
kuliner. Terjadi peningkatan kontribusi pendapatan perempuan pesisir Manokwari dalam Rumah Tangga Perikanan selama 10 tahun (20052015) sebesar 70\%.

\section{DAFTAR PUSTAKA}

Emping JO, Widiastuti N. 2013. Peran Wanitanelayan dalam pemanfaatan sumberdaya perikanan di keluarahan Padarni Kabupaten Manokwari. Skripsi. Tidak dipublikasi. Universitas Negeri Papua. Manokwari.

Firdaus M, Rahadian R. 2005. Peran Istri Nelayan Dalam Meningkatkan Pendapatan Rumah Tangga (Studi Kasus Di Desa Penjajab, Kecamatan Pemangkat, Kabupaten Sambas). Jurnal Sosek KP Vol. 10 No. 2 Tahun 2015: 241249

Harper, S., Zeller D., Hauzer M., Pauly D., Sumaila U.R. 2013. Women and Fisheries: contribution of food security and locall economis. J.marpol, Vol. 39; 56-63. https:// doi.org/10.1016/j.marpol.2012.10. 018

Hikmah, I. 2007. Gender dalam Rumah Tangga Masyarakat Nelayan. Jakarta: Badan Riset Kelautan dan Perikanan.

Jume'edy. 2005. Peran wanita dalam meningkatkan pendapatan keluarga nelayan di kelurahan ujung batu kecamatan jepara kabupaten jepara. Tesis. Program pascasarjana universitas diponegoro program studi magister manajem sumberdaya pantai. Hal 13:14.

Kusnadi. 2003. Akar kemiskinan nelayan. Yogyakarta LKIS

Kusnadi. 2014. Perempuan Pesisir. Yogyakarta LKIS

Putri, N.P.K., Suratiyah, dan S. Hardyastuti. 2007. Wanita diantara kerja dan rumah tangga (Studi kasus pada buruh wanita industri jamur di desa hargo-binangun, kec Pakem, Kab Sleman DIY) Piramida, Jurnal kependudukan dan pengemba-ngan SDM.III (I) hal 41

Sabariah V., dan Tebaiy S. (2005). Peran Perempuan Papua dalam Mening-katkan Pendapatan Keluarga Khususnya Rumah Tangga Peri-kanan, (studi kasus nelayan asli di Manokwari). Jurnal Perikanan dan Kelautan Berkala Ilmiah Penelitian Perikanan dan Kelautan UNIPA, Vol 1 Nomor 2, Novem-ber

Singarimbun, M, dan S, Effendi. 1989. Metode penelitian survey. LP3ES. Jakarta

Soekartawi. 1995. Analisis Usahatani. UI Press, Jakarta

Suparmoko, 1985. Research Practice Method: for Socio and Economic Science. BPFE. Yogyakarta. 294 p. (in Indonesian). Riduwan Drs. MBA. 2002. Skala Pengukuran variable-variabel penelitian. $\mathrm{Pe}$ nerbit Alfabeta Bandung, 189 hal.

Wahyono A. 2001. Pemberdayaan masyarakat nelayan. Jogjakarta. Penerbit Media Pressindo.

Yulistin M dan Nasution Z. 2009. Produktivitas istri dalam penguatan ekonomi rumah tangga nelayan. Dinamika peran Gender dan diseminasi inovasi. BBRSEKP, Badan Riset Kelautan dan Perikanan, Departemen Kelautan dan Perikanan. Jakarta.

Zen L.W. 2008. Analisis Kontribusi Pendapatan Wanita Nelayan di Kelurahan Pasie Nan Tigo Kecamatan Koto Tangah Kota Padang. Fakultas Perikanan dan Ilmu Kelautan, Universitas Bung Hatta Padang. Jurnal Mangrove dan Pesisir IX (1), Februari 2009: 12-17 ISSN: 1411-0679. 